\title{
Distribution and Association of Arbuscular Mycorrhizal Fungi in Different Cultivars of Wheat from Lalganj Pratapgarh District of Utter Pradesh, India
}

\section{O. P. Dwivedi}

Lab of Mycology and Plant Pathology, P.G. Department of Botany, S.V.M. Science \& Technology P. G. College Lalganj, Pratapgarh 230132, Uttar Pradesh, India

Email: dropd@rediffmail.com

Received 29 March 2015; accepted 12 May 2015; published 15 May 2015

Copyright (C) 2015 by author and Scientific Research Publishing Inc.

This work is licensed under the Creative Commons Attribution International License (CC BY).

http://creativecommons.org/licenses/by/4.0/

$$
\text { (c) (i) Open Access }
$$

\begin{abstract}
Arbuscular mycorrhizal fungi are key components of soil micro-flora and obviously interact with other microorganisms in the rhizosphere which is the zone of influence of plant roots on microbial populations and other soil constituents. Keeping in view the importance of AM fungi, the present study was undertaken for assessing the AM fungal spore population dynamics in the rhizosphere soil and its colonization in rhizosphere soils in relation to soil physico-chemical factors. Present study represents an attempt to establish the qualitative and quantitative distribution of AM fungal species in rhizosphere soils of wheat. Thirteen different wheat cultivars collected from four different sites of Lalganj Pratapgarh (U.P.), India were examined for the AM infection. All the wheat cultivars were found to be infected with arbuscular mycorrhizae. However, their population in rhizosphere and root infection varied to a considerable extent from species to species. The maximum spore population and highest percentage of root colonization were found with the rhizosphere soil of cultivars Ankur Kedar.
\end{abstract}

\section{Keywords}

AM Fungi, Root Colonization, Wheat Cultivar

\section{Introduction}

The distribution of the initiation of infection on roots by soil-born fungi is of interest in connection with my-

How to cite this paper: Dwivedi, O.P. (2015) Distribution and Association of Arbuscular Mycorrhizal Fungi in Different Cultivars of Wheat from Lalganj Pratapgarh District of Utter Pradesh, India. Advances in Bioscience and Biotechnology, 6, 353357. http://dx.doi.org/10.4236/abb.2015.65034 
corrhizas as well as pathogens. It can indicate whether particular regions of the root and hence particular cell types or tissues can be infected, or whether susceptibility is a general property, not strongly influenced by differentiation. This may be important in determining whether developmental changes are associated with lack of infectibility and what single molecules or nutrients from the root are involved in the interactions, which lead to infection. The distribution of microorganisms on the root surface depends on the distance of the surface from the apex i.e. on the age of that part of the root. The apex itself (including the root cap) is often free of microbial colonization. Behind this zone, the population increases rapidly and then may stabilize or decline, in response to the availability of nutrients, competition and predation. Some root infecting pathogen (e.g. some Phytopthora and Fusarium spp.) preferentially infect the immediate sub apical regions of the root and this has been presumed to be associated with either lower resistance of juvenile (undifferentiated) tissues or with increased exudation of nutrients. Other fungi, like Gaeumannomyces graminis, are capable of infecting for much longer distances behind the apex. Such fungi can grow extensively on the surface of the root before producing entry points and colonizing the tissues. In this, they are similar to vesicular-arbuscular mycorrhizal fungi, which can colonize from soil-born propagules (primary infection) or from surface hyphae growing from an established infection on the same or a different root (secondary infection). With VAM fungi, it is known that infection can occur up to several centimeters behind the root apex. However, several workers have reported that infections do not occur at the apex and in the apical $10-15 \mathrm{~mm}$ region, leading to the suggestion that this region may not be susceptible [1].

AM fungi are known to be distributed throughout the world in environment ranging from tropical rainforest to arctic tundra. They are present in the soil, in form of chlamydospores, zygospores, and azygospores and have been recovered from the soils of a variety of habitats, e.g. nutrient deficient soils, sand dunes and desserts, industrial wastes, sodic soils, polluted sites, sewage, eroded sites and others like forests, open wood lands, scrub, savanna, heaths, grasslands, anthracite and bituminous cole waste [2]. There are several reports of AM fungi from diverse habitats also from India. AM association occurs widely throughout the plant kingdom. They have been reported to be present in Bryophytes, Pteridophytes, Gymnosperms and Angiosperms in nearly all the geographical regions of the world. Most of the agricultural and horticultural crops belonging to diverse families have been shown to form AM. Many species of plants of economically important families have been reported to be mycorrhizal. Likewise, many of the plantation crops like coffee, tea, rubber, citrus, coca, oil palm and timber trees and many of the fruit trees and medicinal plants have been shown to form VA mycorrhiza. Conclusive evidences are lacking, but a limited number of plant species especially belonging to hydrophytes, halophytes and xerophytes are regarded as non-mycorrhizal. In few families, viz. Cruciferae, Chenopodiaceae, Caryophyllaceae, and Cyperaceae, AM infection is rare or absent. Individual species of AM fungi may be present in diversity of habitats. The occurrence of some other common species of AM fungi suggests that they show little habitat specificity. Morphological differences among species and isolates of AM fungi are minimal, but physiological disparities may be much more pronounced. Many studies have demonstrated that endomycorrhizal fungi are sensitive to environmental conditions, especially those of the soil.

During the past decade, it has been established that AM influences soil fertility and thus the growth and development of plant, and therefore, these can be an alternative to rising agricultural and fertilizer costs. All soils contain either spores of AM fungi or mycorrhizae formed by them. The importance of these fungi has been widely accepted, although their relevance under normal agricultural condition in most cases is difficult to assess experimentally because most soils contain indigenous endomycorrhizal fungi. The indigenous AM fungi are inefficient and inoculation of only efficient strains may be rewarding. Selection of a proper inoculum is essential, since the population of indigenous AM fungi may be an interfering factor in the activities of the introduced ones. A number of factors have been shown to govern the response of the host to an inoculants, viz. type and density, infection potential, site of placement, spread and competitive abilities, etc. The four major factors can determine the success of the inoculation like crop species involving the size, effectiveness of the indigenous AM fungal population, fertility of the soil and cultural practices. It is also important to know which plant species derives more benefit from mycorrhiza. Good establishment in the soil and residual effect of introduced AM fungi have important implication in the tropics because of intensive cropping pattern. Good residual effect saves the expenses of re-inoculation and may enhance rapid infection, which is important for short duration crops. But the persistence of introduced AM fungi will depend on its ability to cope with physical and biological stresses. Only few reports on the persistence of AM fungi are available. Therefore, the present experiment was undertaken to find out qualitative and quantitative distribution of AM fungi, occurring naturally in the agricultural field of wheat at four different study sites of this region. 


\section{Materials and Methods}

The present study represents an attempt to establish the qualitative and quantitative distribution of AM fungal species in rhizosphere soils of wheat. Study was taken up in four different sites e.g. I-Agai, II-Amawa, III-Dagrara and IV-Pharpur of Lalganj, Pratapgarh (U.P.) form November 2009 to October 2012. The soil properties of study sites were also analyzed. The rhizosphere soil samples from 10-20 cm. depths were collected from 13 cultivars i.e. PBW-343, PBW-373, PBW-502, PBW-443, UP-2338, PBW-17, Ganga Kaveri-7777, HD-2733, HUW-468, WHD-943, UP-2382, Ankur Kedar and Kundan of wheat plants. The AM spores were isolated from the each soil samples by wet sieving and decanting techniques of Gerdeman and Nicolson [3]. Healthy AM spores are flushed in to petridishes and counted under a steriozoom dissecting microscope. All healthy spores were mounted in polyvinyl alcohol-lactoglycerol (PVLG), examined for their various morphological characters and identified with the help of identification manual provided by Schenck and Perez [4]. Species codes of AM fungi were assigned following guidelines of Perez and Schenck [5]. The fine roots were stained by using Phillips and Haymen's [6] staining procedure. The percent mycorrhizal colonization was calculated by following formula.

$$
\% \text { Root Colonization }=\frac{\text { No.Segments Colonized with VAM }}{\text { Total No.of segment Observed }} \times 100
$$

AM fungal species association and their relative density with each wheat cultivar at different study sites were calculated by following formula.

$$
\text { Relative Density }=\frac{\text { No.VAM species associated with the host species }}{\text { Total No.of VAM species associated with all the host considered }} \times 100
$$

The two sites of presence/absence of VAM species were compared at time and likewise all the sites were compared taking paired data. Similarity index was calculated by using the following formula:

$$
\mathrm{S}=\frac{2 C}{A+B} \times 100
$$

where, $A=$ No. of species at site I;

$B=$ No. of species at site II;

$C=$ No. of species common to both the sites.

Statistical analysis of data for comparison of means and analysis of variance (ANOVA) was followed after Gupta and Kapoor [7].

\section{Results and Discussion}

Result in Table 1 represented that the maximum spore population was found with the rhizosphere soil of cultivars Ankur Kedar in site III (164 spores) followed by site IV (156 spores), site I (154 spores) and site II (112 spores) with cultivar Kundan in order. The highest percentage of root colonization was observed in site IV (93\%) followed by site I (92\%), site III (91\%) with cultivar Ankur Kedar and site II (72\%) with cultivar Kundan. The maximum root vesicles were present in site IV $\left(43 \mathrm{~cm}^{-1}\right.$ root bit) followed by site I ( $39 \mathrm{~cm}^{-1}$ root bit), site III (39 $\mathrm{cm}^{-1}$ root bit) and site II $\left(32 \mathrm{~cm}^{-1}\right.$ root bit). The results showed that the maximum species were found in site III (54 species) and the density was recorded maximum (14.21) followed by site IV (53 species) and the density was (14.20), site I (51 species) and the density was (10.94) and site II (48 species) and the density was (11.37). Statistical analysis of the experiment is presented in the form of ANOVA. It is clearly evident from the analysis that the site wise variances in the distribution of VAM fungal species are significant at $\mathrm{P}<0.05$ and highly significant for different wheat cultivar at $\mathrm{P}<0.001$ (Table 2). As evident from the result that sites I and II were closer as they showed $96.20 \%$ similarity followed by sites I and IV $(95.48 \%)$ then the site I, II and site III, IV $(92.81 \%)$ site II and III (91.39\%) and least similarity (90.54\%) was found between site II and IV (Table 3).

The physico-chemical properties of soils of all the four sites were different. The texture of soil was clay sand at sites I and IV and clay at sites II and III with grey colour. The pH of the soils was found 7.1 at site I and 7.5 in other three sites. Available soil phosphorus (P) was found maximum at site IV $\left(11.2 \mathrm{Kg} \cdot \mathrm{ha}^{-1}\right)$ and minimum at site I $\left(9.1 \mathrm{Kg} \cdot \mathrm{ha}^{-1}\right)$; nitrogen $(\mathrm{N})$ content was maximum at site II $\left(520.3 \mathrm{Kg} \cdot \mathrm{ha}^{-1}\right)$ and minimum at site III (362.1 
Table 1. Root colonization, average number of vesicles, spore population, total number of AM species associated and their relative density with selected wheat cultivars at different study sites.

\begin{tabular}{|c|c|c|c|c|c|c|c|c|c|c|c|c|c|c|c|c|c|c|c|c|c|}
\hline \multirow{3}{*}{ S. No. } & \multirow{3}{*}{ heat Cultivars } & \multicolumn{4}{|c|}{$\begin{array}{l}\text { Root Coloniza- } \\
\text { tion } \\
(\%)\end{array}$} & \multicolumn{4}{|c|}{$\begin{array}{l}\text { Average No. of } \\
\text { Vesicles } \\
\text { (cm }{ }^{-1} \text { Root Bit) }\end{array}$} & \multicolumn{4}{|c|}{$\begin{array}{c}\text { Spore Population } \\
\left(50 \text { gm }^{-1}\right) \\
\text { Rhizosphere Soil }\end{array}$} & \multicolumn{4}{|c|}{$\begin{array}{l}\text { Total No. of AM } \\
\text { Fungal Species }\end{array}$} & \multicolumn{4}{|c|}{$\begin{array}{c}\text { Relative Density of AM } \\
\text { Fungi }\end{array}$} \\
\hline & & \multicolumn{20}{|c|}{ Study Sites } \\
\hline & & I & II & III & IV & $\mathbf{I}$ & II & III & IV & I & II & III & IV & I & II & III & IV & I & II & III & IV \\
\hline 1. & & 86 & 56 & 79 & 85 & 36 & 31 & 39 & 43 & 117 & 105 & 109 & 117 & 41 & 44 & 46 & 46 & 8.79 & 10.42 & 12.10 & 12.33 \\
\hline 2. & & 62 & 46 & 67 & 79 & 24 & 28 & 29 & 39 & 98 & 92 & & 102 & 34 & 32 & 31 & 33 & 7.29 & 7.58 & 8.15 & 8.84 \\
\hline 3. & & ND & 43 & ND & ND & ND & 21 & ND & ND & 75 & 82 & 69 & 63 & 30 & 29 & 28 & 26 & 6.43 & 6.87 & 7.36 & 6.97 \\
\hline 4. & & 68 & ND & 37 & ND & 34 & ND & 22 & ND & 103 & 54 & 58 & 56 & 35 & 23 & 25 & 24 & 7.51 & 5.45 & 6.57 & 6.43 \\
\hline 5. & D 2230 & 54 & 37 & 58 & 62 & 21 & 22 & 23 & 29 & 89 & 76 & 82 & 82 & 31 & 28 & 30 & 27 & 6.65 & 6.63 & 7.89 & 7.23 \\
\hline 6. & & 68 & 48 & $\mathrm{NC}$ & 59 & 37 & 18 & $\mathrm{NC}$ & 22 & 108 & 87 & $\mathrm{NC}$ & 76 & 36 & 29 & $\mathrm{NC}$ & 27 & 7.72 & 6.87 & $\mathrm{NC}$ & 7.23 \\
\hline 7. & Ganga Kaveri-7777 & 57 & ND & 53 & $\mathrm{NC}$ & 26 & ND & 18 & $\mathrm{NC}$ & 90 & 85 & 72 & $\mathrm{NC}$ & 32 & 29 & 29 & $\mathrm{NC}$ & 6.86 & 6.87 & 7.63 & $\mathrm{NC}$ \\
\hline 8. & & 76 & ND & $\mathrm{NC}$ & $\mathrm{NC}$ & 39 & ND & $\mathrm{NC}$ & $\mathrm{NC}$ & 108 & 59 & $\mathrm{NC}$ & $\mathrm{NC}$ & 35 & 26 & $\mathrm{NC}$ & $\mathrm{NC}$ & 7.51 & 6.16 & & $\mathrm{NC}$ \\
\hline 9. & JW & 47 & 50 & ND & ND & 25 & 19 & ND & ND & 86 & 87 & 52 & 93 & 31 & 29 & 25 & 28 & 6.65 & 6.87 & 6.57 & 7.50 \\
\hline 10. & & 72 & 32 & 62 & 65 & 19 & 20 & 26 & 32 & 95 & 62 & 86 & 89 & 32 & 26 & 31 & 27 & 6.86 & 6.16 & 8.15 & 7.23 \\
\hline 11. & & ND & 52 & 65 & 75 & ND & 25 & 17 & 35 & 65 & 98 & 89 & 98 & 29 & 33 & 31 & 29 & 6.22 & 7.81 & 8.15 & 7.77 \\
\hline 12. & Ankur Kedar & 92 & 68 & 91 & 93 & 27 & 30 & 34 & 28 & 154 & 108 & 164 & 156 & 51 & 46 & 54 & 53 & 10.94 & 10.30 & 14.21 & 14.20 \\
\hline 13. & Kundan & 88 & 72 & 87 & 88 & 32 & 32 & 35 & 34 & 124 & 112 & 149 & 147 & 49 & 48 & 50 & 53 & 10.51 & 11.37 & 13.15 & 14.20 \\
\hline
\end{tabular}

ND—Not Detected; NC—Not Cultivated.

Table 2. Comparison of different study sites for the cultivation of selected wheat cultivars with no. of AM species association.

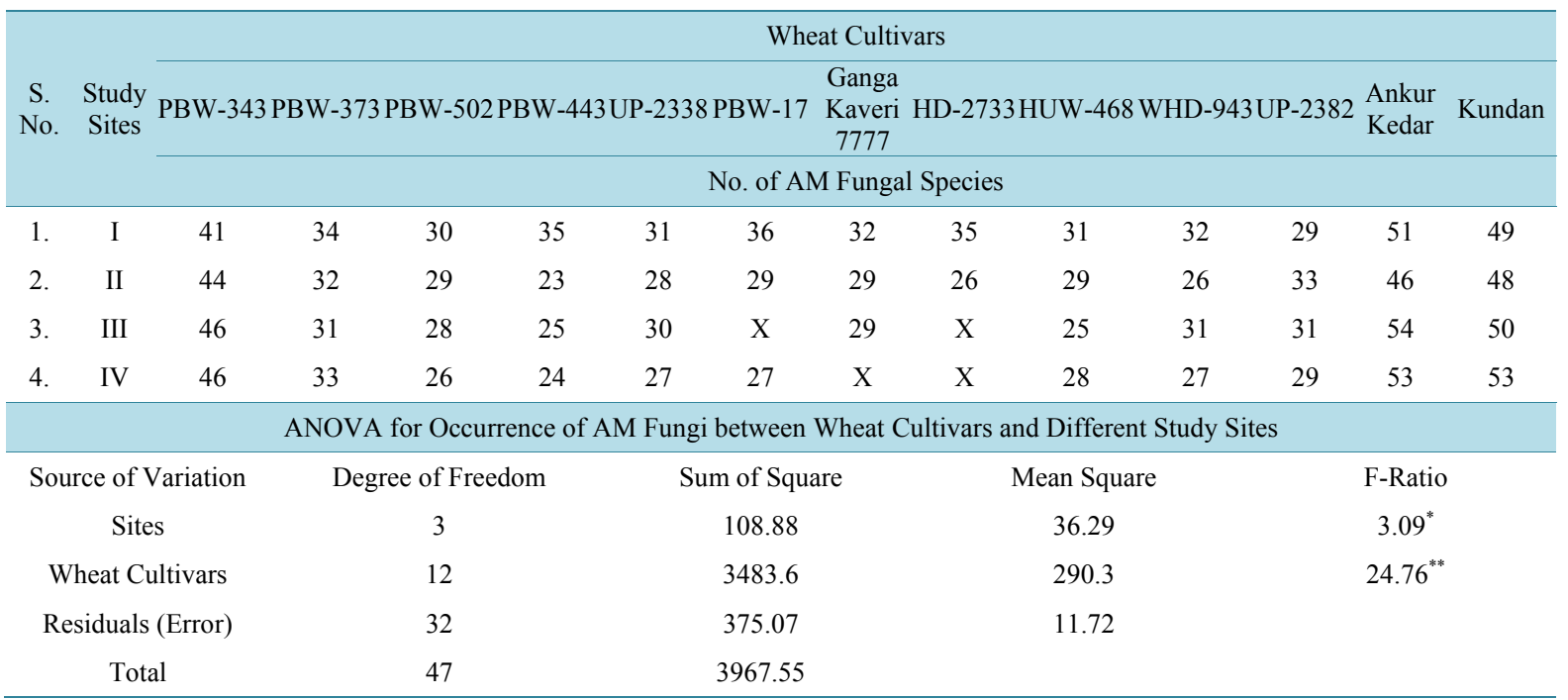

"Significant at $\mathrm{P}<0.05 ;{ }^{* *}$ Significant at $\mathrm{P}<0.001$

Table 3. Similarity matrix of different study sites for the occurrence of AM fungi.

\begin{tabular}{cccc}
\hline & Study Sites & \\
\hline I & II & III & IV \\
I & 2.81 & 96.20 & 95.48 \\
II & & 91.39 & 90.54 \\
III & & & 92.81 \\
\hline
\end{tabular}


$\left.\mathrm{Kg} \cdot \mathrm{ha}^{-1}\right)$ while potassium $(\mathrm{K})$ was highest at site II $\left(226.0 \mathrm{Kg} \cdot \mathrm{ha}^{-1}\right)$ and lowest at site I $\left(190.0 \mathrm{Kg} \cdot \mathrm{ha}^{-1}\right)$.

In present investigation, the result revealed that occurrence of AM fungi within the root as symbiont and in the vicinity was widespread irrespective of different habitats as they were found in all the test sites. Results suggest that the percent colonization, average number of vesicle, spore population, and total AM fungal species differ with different cultivars of wheat in different test sites. The diversity and distribution of AM fungi in different sites may be attributed to the different physico-chemical properties of soil. This is also reported in the rhizosphere soils of mungbean and soybean [8]. The AM root infection is a dynamic process, which is influenced by edaphic factor such as seasons, AM strains, soil temperature, soil $\mathrm{pH}$, host cultivar susceptibility to AM colonization and feeder root condition at tissue of sampling. This corroborated earlier findings [9]-[11]. The quantity and type of AM propagules also affected the dynamics of root infection, which were also increased by increasing the age of plant [12].

Results of present study conclude that occurrence of AM fungi varies with host ranges. Though they are ubiquitous, they show specificity in association with host plants. All the AM species did not occur in all the areas and not all the species had the same effect on their symbiont. Different species and different isolates within species can have different effects on one plant growth. However, biomass production by most of the plant species varied significantly among treatments with different single AM taxa.

\section{References}

[1] Harley, J.L. and Smith, S.E. (1983) Mycorrhizal Symbiosis. Academic Press, London, New York, 483.

[2] Chandra, S. (1992) VA-Mycorrhiza-Dimensions of Its Application. Indian Phytopathology, 45, 391-406.

[3] Gerdemann, J.W and Nicolson, T.H. (1963) Spores of Mycorrhizal Endogone Species Extracted from Soil by Wet Sieving and Decanting. Transactions of the British Mycological Society, 46, 235-244. http://dx.doi.org/10.1016/S0007-1536(63)80079-0

[4] Schenck, N.C. and Perez, Y. (1987) Manual for Identification of VAM Fungi. Synergistic Pub., Gainesville.

[5] Perez, Y. and Schenck, N.C. (1990) A Unique Code for Species of VAM Mycorrhizal Fungi. Mycologia, 82, 256-260. http://dx.doi.org/10.2307/3759855

[6] Phillips, J.M. and Hayman, D.S. (1970) Improved Procedures for Clearing Roots and Staining Parasitic and Vesicular-Arbuscular Fungi for Rapid Assessment of Infections. Transactions of the British Mycological Society, 55, 158-160. http://dx.doi.org/10.1016/S0007-1536(70)80110-3

[7] Gupta, S.C. and Kapoor, V.K. (1997) Fundamentals of Applied Statistics. 3rd Edition, Sultan Chand and Sons, New Delhi, 6.1-6.113.

[8] Hindumathi, A. and Reddy, B.N. (2011) Occurrence and Distribution of Arbuscular Mycorrhizal Fungi and Microbial Flora in the Rhizosphere Soils of Mungbean [Vigna radiata (L.) Wilczek] and Soybean [Glycine max (L.) Merr.] from Adilabad, Nizamabad and Karimnagar Districts of Andhra Pradesh State, India. Advances in Bioscience and Biotechnology, 2, 275-286. http://dx.doi.org/10.4236/abb.2011.24040

[9] Dwivedi, O.P. (2008) Distribution of Seasonal Variation in VAM Fungi on Winter Wheat Cultivar C-306. Indian Phytopathology, 61, 273-276.

[10] Dwivedi, O.P. (2013) Distribution of Arbuscular-Mycorrhizal Fungi in Different Cultivars of Wheat. Indian Phytopathology, 66, 220-223.

[11] Dwivedi, O.P., Yadav, R.K., Vyas, D. and Vyas, K.M. (2003) Distribution of AM Fungi in the Rhizosphere Soils of Betel Vine. Indian Phytopathology, 56, 228-229.

[12] Chandra, K.K. and Jamuluddin (1999) Distribution of Vesicular Arbuscular Mycorrhizal Fungi in Coalmine Overburden Dumps. Indian Phytopathology, 52, 254-258. 